\title{
Człowiek, czas i miejsce w wybranych opowiadaniach Vaqifa Sultanlego na tle sytuacji politycznej we współczesnym Azerbejdżanie
}

$\mathrm{E}$

rnest Cassirer w Eseju o człowieku pisał: „Czas i przestrzeń są ramami, które zamykają w sobie całą rzeczywistość. Nie możemy pojąć żadnej rzeczy realnej inaczej, jak tylko w warunkach czasu i przestrzeni"292. Obie te kategorie odnoszą się do egzystencji człowieka, a w procesie percepcji tekstu literackiego sprawiają, że czytelnik - oprócz pytania „kim jestem?” - niechybnie musi sobie także zadać pytanie „kiedy jestem?” oraz „gdzie jestem?". Przy czym termin 'przestrzeń w dziele literackim' oznacza - powtarzając za Henrykiem Markiewiczem - nie tylko pewne fragmenty przestrzeni w sensie geometrycznofizycznym, a więc terytorium (np. krajobrazy, wnętrza), ale także przedmioty naturalne i wytworzone przez człowieka, jak i zjawiska przyrody ${ }^{293}$. Kategorie czasu i przestrzeni są w dziele literackim nierozłączne, a ich funkcje $w$ kreowaniu bohaterów i świata przedstawionego - bardzo zbliżone. Zagadnienie to uczyniła jednym z najważniejszych tematów badawczych Anna Martuszewska ${ }^{294}$, odwołując się przy tym do ustaleń pioniera badań nad koncepcją czasu i „czasoprzestrzeni”295 w literaturze, Michaiła Bachtina. Badacze podkreślają wagę kategorii czasu i przestrzeni jako czynników wpływających na oś konstrukcyjną i fabularną dzieła literackiego oraz na kreację postaci literackiej.

Przedmiotem analizy w niniejszym tekście są właśnie te trzy zasadnicze komponenty (czas, przestrzeń i bohater) składające się na fabułę opowiadań przedstawiciela współczesnej prozy azerbejdżańskiej, Vaqifa Sultanlego. ${ }^{296}$

\footnotetext{
${ }^{292}$ E. Cassirer, Esej o czlowieku. Wstęp do filozofii kultury, [tłum.] A. Staniewska, Warszawa 1977, s. 108, [cyt. za:] T. Gęsina, Co było przed geopoetyka? Kategoria przestrzeni w literaturoznawstwie polskim - rekonesans, „Postscriptum Polonistyczne” 2016, nr 1 (17), s. 167.

${ }^{293}$ Zob.: H. Markiewicz, Czas i przestrzeń w utworach narracyjnych, Kraków 1983, [nadb.] „Ruch Literacki”, XXIV, z. 1 (136), s. 10.

${ }^{294}$ Zob.: A. Martuszewska, Czas i przestrzeń w polskiej powieści wspótczesnej dojrzałego realizmu, „Pamiętnik Literacki" 1975, 66/1, s. 3-23.

${ }^{295}$ Przez „czasoprzestrzeń” rozumiemy w badaniach literackich, rzecz jasna, nie termin stosowany w fizyce od czasów Einsteina, a „wzajemne powiązanie stosunków czasowych i przestrzennych przyswojonych artystycznie w literaturze" (M. Bachtin, Formy czasu i czasoprzestrzeni w powieści, [w:] eadem, Problemy literatury $i$ estetyki, [tłum.] W. Grajewski, Warszawa 1981, s. 279). Upraszczając tę definicję można powiedzieć, że czasoprzestrzeń w literaturze to korelacja elementów czasowych i przestrzennych w utworze literackim.

${ }^{296}$ Vaqif Sultanlı (czyt. Wagif Sultanly). W polskiej tradycji językowej utrwaliła się już reguła odmiany obcych nazwisk zakończonych na samogłoskę ' $y$ ' (np. Batory - Batorego), w związku z czym autorka zdecydowała się na odmienianie nazwiska Sultanlı według tego schematu, choć wspomniana reguła mówi o nazwiskach spolszczonych, przede wszystkim pochodzenia węgierskiego i z wygłosem zapisywanym literą ' $y$ '.
} 
Wybór tego pisarza spośród dziesiątków współczesnych prozaików Azerbejdżanu nie był przypadkowy. Po pierwsze, autorka artykułu zna go osobiście, od lat zna jego twórczość (trzy opowiadania przełożyła na język polski ${ }^{297}$ ), a możliwość kontaktu z pisarzem jest niewątpliwym atutem $\mathrm{w}$ procesie badań literackich, jako że badacz - w przypadku wątpliwości co do interpretacji - nie jest zdany wyłącznie na siebie i własną intuicję. Po drugie, Vaqif Sultanlı ze swoją nadzwyczaj aktywną działalnością akademicką, literacką, wydawniczą i z dorobkiem na polu zacieśniania kontaktów rozrzuconej po świecie azerbejdżańskiej diaspory, z całą pewnością zasługuje na przedstawienie polskim czytelnikom jako wzór naukowca i pisarza angażującego się w wysiłki na rzecz walki o jedność narodową. Sygnalizowany w temacie artykułu przedmiot rozważań (człowiek, czas i miejsce) zostanie omówiony na przykładzie czterech opowiadań z różnych okresów twórczości Vaqifa Sultanlego. Najstarsze z nich to jego pierwsze opowiadanie (Zapach piołunu, 1978).

\section{Vaqif Sultanlı - krótka biografia}

Vaqif Sultanlı urodził się w 1958 roku w Şahsevən, w okręgu Kürdəmir. Po skończeniu wiejskiej szkoły średniej oraz szkoły muzycznej, w której pobierał naukę gry na tradycyjnym azerbejdżańskim instrumencie tar, w latach 1976-81 studiował literaturę na Państwowym Uniwersytecie w Baku. Po ukończeniu studiów został skierowany do pracy we wsi Qalaciq (rejon İsmayıllı) jako nauczyciel języka i literatury azerbejdżańskiej. W roku 1984 uzupełnił studia II stopnia i rozpoczął działalność naukową. Od 1999 roku jest profesorem. Pracuje cały czas na tym samym uniwersytecie, w Zakładzie Historii Literatury Azerbejdżanu, specjalizując się we współczesnej literaturze azerbejdżańskiej, a szczególnie w dziedzinie teorii i krytyki oraz literatury emigracyjnej. Jest autorem dziesięciu monografii naukowych i podręczników akademickich. Wśród jego książek wyróżnia się monografia poświęcona wybitnemu działaczowi niepodległościowemu związanemu przez wiele lat $\mathrm{z}$ Polską, Mehmedowi Eminowi Resulzade (Məhəmməd Omin Rasulzadənin adəbi dünyası [Świat literacki Mehmeta Emina Resulzade], 1993). W roku 1995 prowadził w Polsce kwerendę. Jest autorem olbrzymiej liczby artykułów naukowych i esejów dotyczących historii literatury, krytyki i badań literackich. Ważną częścią jego dorobku są referaty, które wygłasza na międzynarodowych sympozjach w wielu krajach świata od Chin i Korei przez Indie i Azję Centralną, Turcję i północny Cypr po Francję, Wielką Brytanię i Stany Zjednoczone. Warto w tym miejscu wspomnieć, że w roku 1991 Sultanlı założył międzynarodową organizację skupiającą badaczy Azerbejdżanu (Ümumdünya Azərbaycanşünaslar Assosiasiyası [The World Association of Azerbaijani Studies]) i był jej pierwszym przewodniczącym. W latach 2002-2012 pełnił obowiązki redaktora naczelnego czasopisma „Dünya Azərbaycanlıları” ukazującego się w Stanach Zjednoczonych i reprezentującego głos szeroko pojętej azerbejdżańskiej diaspory. W roku 2018 został przyjęty do International Writers Association z siedzibą w Stanach Zjednoczonych.

\footnotetext{
${ }^{297} \mathrm{Na}$ język polski przetłumaczono następujące opowiadania Vaqifa Sultanlego: Xallı (Buraska, „Przegląd Orientalistyczny" 2007, nr 3-4, s. 221-223); Vatan (Ojczyzna, [w:] Czerwona limuzyna. Antologia współczesnej prozy azerbejdżańskiej, Warszawa 2007, s. 131-134); Tars Axın (Odwrócony strumień, opowiadanie jeszcze nieopublikowane).
} 
Bardzo ważną częścią aktywności życiowej Vaqifa Sultanlego, obok pracy pedagogicznej, naukowej, działalności organizacyjnej i felietonistyki, jest twórczość literacka. Zaczął pisać jeszcze podczas studiów, debiutując pod koniec lat 70. opowiadaniami na łamach prasy. Opublikował dwie powieści i cztery tomy opowiadań. Jego dzieła, zarówno naukowe jak i literackie, tłumaczone są na języki obce, m. in. na angielski, turecki, perski, rosyjski, niemiecki, arabski, uzbecki. Opublikował także cztery antologie współczesnej prozy azerbejdżańskiej. Trzy z nich ukazały się po angielsku w Wielkiej Brytanii ${ }^{298}$, a jedna dotyczy mało znanej i niedostępnej dla mieszkańców Azerbejdżanu prozy ich pobratymców z Azerbejdżanu Południowego czyli tej większej części Azerbejdżanu, która dawnymi decyzjami władców znalazła się w obcym państwie, w Iranie ${ }^{299}$.

\section{Zapach piołunu - letni obrazek ze wsi radzieckiego Azerbejdżanu}

Opowiadanie Zapach piołunu (azerb.: Yovşan atri) z roku 1978 to pierwszy opublikowany utwór pisarza. Główny bohater, student İsmail, właśnie przyjechał z Baku do swojej rodzinnej wioski:

„Popękaną od słońca drogą, która wiła się wśród sięgającej horyzontu równiny porośniętej piołunem, szedł młody człowiek z walizką. Raz po raz przekładał bagaż $z$ ręki do ręki i nie przystając ani na chwilę, szedł równomiernym, ciężkim krokiem. Droga dłużyła się niemiłosiernie. Nie minął go żaden pojazd, ani żadne żywe stworzenie. Ponieważ od dawna nie było deszczu, spod jego stóp wzbijały się tumany kurzu. W powietrzu unosił się ciężki, ostry zapach piołunu. Ale on nie dostrzegał tumanów kurzu, ani nie czuł palącego zapachu. Jego pamięć i uczucia były stępione niczym dawno nieużywany nóż”300.

İsmail przyjechał tylko na jedną noc, a powód przyjazdu jest bardzo smutny. Kilka miesięcy wcześniej zmarła jego matka, a on - nie mogąc przyjechać na pogrzeb, ani później - dopiero teraz przyjeżdża po raz pierwszy do domu rodzinnego. Do domu bez matki. Witają go pogrążeni w rozpaczy ojciec i siostry. W tym domu nic już nie jest takie, jakie było za życia matki i nigdy już takie nie będzie. Dom jest zaniedbany, nie widać w nim troskliwej ręki kobiety. Piękny ogród, w który matka wkładała całe swoje serce, zarósł chwastami. Wszędzie widać piołun, a zapach tego chwastu towarzyszy İsmailowi przez cały czas pobytu w domu. Opustoszało też jaskółcze gniazdo, które zawsze o tej porze rozbrzmiewało śpiewem.

Chłopak ze zdziwieniem stwierdza, że nawet kury się zmieniły, odkąd nie ma matki. Sprawiają wrażenie, jakby straciły wolę życia. Już nie wchodzą na noc do kurnika, tylko śpią tam, gdzie je noc zastanie: na ziemi, na drzewie. Kiedy chłopak kładzie się spać, zauważa w pokoju przedmioty, które należały do matki, co wyzwala w nim jeszcze większą rozpacz.

\footnotetext{
${ }^{298}$ Modern Azerbaijanian Prose. Anthology, prep. by V. Sultanly and I. Ismaely, Bloomington, 2012; Modern Azerbaijani Women's Prose. Anthology, eadem, Bloomington, 2014; Modern Azerbaijani Prose. Anthology, 2nd edition with additions, eidem, Bloomington, 2019.

${ }^{299}$ Güney Azarbaycan nəsri. Başlanğıcdan bu güna qadər, eidem, Bak1 2017.

${ }^{300}$ V. Sultanlı, Qul bazarı, Bakı 1999, s. 14.
} 
Szczególnie dojmujący jest dla niego widok białej chusty, którą kupił dla matki rok wcześniej, przez długi czas oszczędzając i odkładając na ten zakup drobne pieniądze. I sprawił matce tym prezentem taką radość, że ani razu nie założyła tej chusty na głowę, tylko trzymała w skrzyni jak największy skarb... Rano chłopak idzie na grób matki, a po powrocie $\mathrm{z}$ cmentarza żegna się z rodziną i wyrusza w drogę powrotną do miasta.

Choć w tym opowiadaniu występuje kilka postaci, czytelnik odnosi wrażenie, że bohaterami determinującymi bieg wypadków są tylko dwie osoby: İsmail i jego matka, która - mimo że już nie żyje - jest bardzo mocno obecna w akcji opowiadania. Widzimy ją cały czas poprzez myśli i wspomnienia İsmaila, widzimy ją w bezgranicznym smutku pozostałych domowników, a nawet można zaryzykować stwierdzenie, że również w smutku osieroconych przez nią sprzętów domowych, kur i roślin w ogródku.

$\mathrm{Na}$ miejsce akcji w tym opowiadaniu składają się: wiejska droga od przystanku do domu İsmaila, dom rodzinny, ogródek, cmentarz. Wszystkie te miejsca zdają się być pełne żałoby, tak jakby cierpiały ból razem z pogrążonymi w rozpaczy ludźmi. W jednym zdaniu pojawia się też Baku - miasto studiów İsmaila. Jest to miejsce, do którego z jego rodzinnej wsi jedzie się długo i z przesiadkami.

Czas akcji opowiadania, nieokreślony dokładnie, przypada na gorącą porę roku. Wszystko jest spalone słońcem, nad drogą unoszą się kłęby pyłu, a obezwładniający żar z nieba jeszcze bardziej potęguje bezsilność przybitych smutkiem ludzi. Akcja jest bardzo powolna, statyczna i prawie bezgłośna, nie licząc jednostkowych, krótkich wypowiedzi domowników. Bardzo częstym w utworach Vaqifa Sultanlego zjawiskiem jest retrospekcja. Odnajdujemy ją także w tym opowiadaniu: pisarz kilkakrotnie przywołuje obraz zmarłej matki poprzez ukazanie myśli jej syna.

Choć nie jest to wprost powiedziane, z tekstu możemy się domyślić, że rzecz dzieje się w skolektywizowanej wiosce radzieckiego Azerbejdżanu. Rodzina İsmaila żyje bardzo skromnie w niewielkim wiejskim domu, uprawia nieduży przydomowy ogródek, który pozwala wzbogacić codzienny jadłospis o własne warzywa i owoce, w ogródku trzyma się nieduże, własne stadko kur. Pomimo tych pozorów posiadania „własności prywatnej” życie rodziny i całej społeczności podporządkowane jest regułom wiejskiego kolektywu. Ojciec İsmaila codziennie o świcie wsiada na konia i jedzie do prac polowych, a ze słów jego córek wynika, że pracuje ponad siły. $Z$ elementów, które zaliczyć można do kołchozowej rzeczywistości, pisarz zamieszcza $\mathrm{w}$ fabule wspólne, wiejskie stado bydła, przy którym zatrudniony jest jeden pastuch oraz pełną dziewcząt i młodych kobiet ciężarówkę, która pod wieczór przywozi robotnice $\mathrm{z}$ pola do wsi.

\section{Kilim Babci İnce - oszukując śmierć...}

Opowiadanie Kilim Babci İnce ${ }^{301}$ (azerb.: Incə qarının hanasl) pochodzi z roku 1984. W tej miniaturze zajmującej zaledwie półtorej strony doskonale widać mistrzostwo autora w sztuce budowania akcji: pomimo minimalnych rozmiarów i lapidarnej treści utwór jest bardzo poruszający. Występuje tu tylko jedna postać, tytułowa Babcia İnce. Staruszka przez całe życie tkała kilimy, był to jej zawód i źródło utrzymania. Z umiejętnie wplatanej w akcję

${ }^{301}$ İnce - czyt.: Indże. 
retrospekcji dowiadujemy się, że wyrabiała kilimy dla wszystkich ludzi z okolicy, dla swoich i obcych. Zawsze tkała dla innych. I oto teraz, w czasie, gdy toczy się akcja utworu, staruszka tka ostatni kilim i tka go dla siebie. Wie, że niedługo umrze i że ten ostatni kilim jest dla niej. Wkłada w tę pracę całe swoje serce, swoje uczucia, można rzec - całą siebie. I można powiedzieć, że im więcej wkłada samą siebie w tę pracę, tym bardziej przybliża się do śmierci. Wie, że kiedy skończy tkać, przyjdzie po nią śmierć. A wplatając w kilim kolorowe nici, wplata swoje życie:

„Nić czerwona to była jej krew, żółta to tęsknota, szara to oczy. Nić czarna to jej los, biała to siwe włosy, a niebieska to jej sny. Te kolory żyły i kobieta do rana $\mathrm{z}$ nimi rozmawiała. I kiedy tak tkała, to płakała. Płakała na wspomnienie minionych czasów. Miała na obu policzkach po jednej długiej linii. Wyżłobiły je te łzy, które przelewała nocami. [...] W kilimie, który teraz tkała, było coś magicznego, coś tajemnego. Ten kilim był jej życiem. Jej chorobą. Był jej tęsknotą za wnukami, co poszli na wojnę i już nie wrócili. [...] W tym kilimie były jej sekretne sny, jej wielka miłość i piękno, które dawno utraciła”302.

Ponieważ staruszka czuła, iż żyje tylko dlatego, że jej kilim jeszcze nie jest gotowy, nie dopuszczała do siebie myśli o skończeniu tej pracy. Bo kiedy kilim będzie gotowy - upomni się o nią śmierć. Dlatego gdy codziennie nad ranem widziała, że kilim jest prawie ukończony, pruła go, aby wieczorem zacząć tkać od nowa i w ten sposób odsunąć od siebie śmierć. Ostatnie słowa tego miniaturowego opowiadania brzmią: „Dłużyła się noc. Dłużyło się życie",303.

W tym absolutnie baśniowym, tajemniczym, onirycznym świecie mamy tylko jedną postać, ale w jej wspomnieniach przewijają się ludzie, na których zamówienie przez całe życie wyrabiała kilimy oraz wnukowie, którzy nie wrócili z wojny. Tak więc w tym utworze również mamy do czynienia $\mathrm{z}$ wykorzystaniem retrospekcji dla przekazania bogatszej wiedzy o czasach i ludziach.

Miejsce akcji ograniczone jest do absolutnego minimum - do pokoiku, w którym Babcia İnce mieszka i pracuje. Czas akcji, jak w przeważającej większości utworów Sultanlego, nie został sprecyzowany. Pisarz nie umieścił w tekście żadnych wskazówek, które pomogłyby czytelnikowi domyślić się, na której wojnie zginęli wnukowie bohaterki. Prawdopodobnie była to II wojna światowa. Opowiadanie pozostawia czytelnika z poczuciem wielkiego smutku i ze świadomością, że ofiarami wojny są nie tylko ci, co na nich giną, ale też ci, którzy po nich zostają, a najczęściej są to kobiety i dzieci, boleśnie okaleczone przez utratę najbliższych...

\footnotetext{
${ }^{302}$ Ibidem, s. $90-91$

${ }^{303}$ Ibidem, s. 91.
} 


\section{Buraska - zimowy obrazek ze wsi radzieckiego Azerbejdżanu}

Opowiadanie Buraska (azerb.: Xall) z roku 1999 zaczyna się od opisu mroźnej zimowej nocy, kiedy wśród odgłosów szalejącej śnieżycy kobieta urodziła swoje czwarte dziecko. Płacz noworodka obudził męża kobiety i starsze dzieci. Mężczyzna zaczyna czynić kobiecie wyrzuty, dlaczego go nie obudziła, ale jego pretensje ustąpią miejsca radości, gdy tylko zobaczy dziecko. To chłopak! Po czterech córkach wreszcie syn! Dziewczynki są tej nocy świadkami przedziwnych wydarzeń. W domu pojawiło się nowe dziecko, a ojciec w środku nocy wykonuje czynności, których nigdy wcześniej nie wykonywał nawet w dzień:

„Wyciągnął z kąta sito i zaczął przesiewać mąkę. Aż do tego momentu dziewczynki sądziły, że tylko ich matka to potrafi i dlatego zawsze tylko ona wykonuje tego typu czynności. Przesiewając mąkę ojciec poruszał się z lekka to $\mathrm{w}$ prawo, to w lewo, a mdłe światło lampy rzucało jego cień na ścianę. Cień to rósł, to malał, co sprawiało wrażenie, jak gdyby jakaś straszna zjawa wypełniała izbę. Potem ojciec wziął misę i począł wyrabiać ciasto. Dzieci patrzyły w osłupieniu, jak ojciec przyrządza posiłek. Gdy jedzenie było gotowe, podał matce na talerzu, potem włożył do pieca potężny kawałek drewna i położył się"304.

Tej samej nocy w tym domu urodziła swoje dzieci kotka. Kobieta brzydzi się kotami i toleruje ich obecność tylko dlatego, że ratują domostwo przed myszami. Ale teraz, gdy w domu jest maleńkie dziecko, zabobonna kobieta nie pozwala na obecność kotki, która mogłaby sprowadzić na noworodka nieszczęście. Każe najstarszej córce wynieść kotkę z kociętami. Dziewczynka urządza im kącik w oborze. Nie wiadomo jakim sposobem, brnąc z kociętami w wielkim śniegu, kotka następnej nocy przeniosła swoje dzieci z powrotem do domu. Rano matka znów zawołała do córki: „Zabierz to nieczyste stąd! Ciśnij w śnieg!”305. Dziewczynka znów wyniosła kocią rodzinę do obory.

Tej zimy ludzka rodzina doczekała się wielkiego szczęścia w postaci narodzin syna, lecz kocia matka i jej dzieci nie przeżyły mrozów.

$\mathrm{Na}$ tle innych opowiadań Vagifa Sultanlego Buraska należy do bardziej rozbudowanych pod względem zestawu postaci i przebiegu akcji. Lista postaci jest długa, jak na utwory tego pisarza. Znajdują się na niej: ciężko pracujący na utrzymanie rodziny gderliwy ojciec, który złagodniał i zmienił zachowanie po narodzinach syna; nieczuła, zabobonna matka, której los zesłał radość urodzenia chłopca, ale ona w tym samym czasie skazuje na śmierć kocią matkę i jej dzieci; cztery dziewczynki, pracowite, posłuszne, empatyczne w stosunku do zwierząt. Do tej listy dopisać można postać bardzo ważną, choć zupełnie bierną w tym opowiadaniu - nowo narodzonego chłopca a także tytułową bohaterkę, kotkę, która u większości czytelników wywołuje zapewne znacznie cieplejsze uczucia, niż ludzka matka.

Miejsce akcji prawie w całości związane jest z izbą mieszkalną skromnego wiejskiego domu. Nieliczne, krótkie epizody prowadzą czytelnika do przydomowej stajni, gdzie rozgrywa się tragedia kociej rodziny. Dom i stajnia to zasadnicze miejsca, w których pisarz

${ }^{304}$ Eadem, Buraska, [thum.] G. Zając, „Przegląd Orientalistyczny” 2007, nr 3-4, s. 221-222.

${ }^{305}$ Ibidem, s. 223. 
ulokował akcję opowiadania, ale wspomina się jeszcze o jednym - bliżej nieokreślonym miejscu pracy ojca. Przy okazji dowiadujemy się też, że w tej wiosce, która jest zapewne typową niedużą miejscowością na azerbejdżańskiej prowincji, działa sklep:

„Tego dnia ojciec wcześniej wrócił z pracy. W rękach trzymał papierową torbę z owocami, cukierkami i innymi drogimi prezentami. Oczy miał roześmiane, cieszył się jak dziecko. [...] W jego twarzy widać było taką dumę, jakby to nie jego kobieta, a on sam urodził tego chłopca"306.

Czas w tym opowiadaniu obejmuje kilka dni ciężkiej, kaukaskiej zimy: od nocy narodzin chłopca do dnia, gdy w stajni znaleziono zamarzniętą kotkę, która wcześniej, z bezsilności, zjadła swoje kocięta. Wybór zimowej pory jako czasu akcji tego opowiadania zapewne nie był przypadkowy a bardzo dobrze przemyślany. Zima to czas próby dla człowieka, czas ciężki do przeżycia. Kiedy $w$ takich trudnych warunkach trzeba walczyć o życie swoje i najbliższych, jedni zdają egzamin z miłosierdzia, inni - nie. W opowiadaniu Buraska autor koncentruje uwagę na właściwym czasie akcji, opisując zdarzenia, które miały miejsce w trakcie tych kilku dni, stąd całkowity brak odwołań do przeszłości. Jest to jedno z nielicznych opowiadań Sultanlego, w których nie korzysta się z retrospekcji.

Podobnie jak w opowiadaniu Zapach piołunu, tutaj również akcja toczy się w skolektywizowanej wsi radzieckiego Azerbejdżanu, w skromnym wiejskim domu. Daty powstania tych utworów dzieli 21 lat, ale wydaje się, że czas akcji w obydwu dotyczy podobnego okresu - lat powolnej, żmudnej budowy socjalistycznego dobrobytu na radzieckiej prowincji. Dobrobytu na miarę lokalnych możliwości...

\section{Ojczyzna - echa konfliktu ormiańsko-azerbejdżańskiego}

Opowiadanie Ojczyzna (azerb.: Vətən) z roku 2002 zaczyna się od opisu trudnej wędrówki głównego bohatera w poszukiwaniu rodzinnej krainy, tytułowej ojczyzny. Czytelnik przez dłuższy czas nie zdaje sobie sprawy, kim jest bohater, którego oczami oglądamy świat i z którego uczuciami tak mocno, tak ,po ludzku”, identyfikujemy się. Już od pierwszych akapitów odruchowo stajemy po stronie wygłodzonego wędrowca, któremu po wielu dniach ciężkiej drogi udało się odnaleźć swoją dawną wioskę, leżącą teraz - po dramatycznych zawirowaniach wojennych - po drugiej stronie granicy, i liczymy na to, że dalszy bieg wypadków doprowadzi utrudzonego bohatera do szczęśliwego zakończenia.

„Zatrzymał się przed zagrodą, w której kiedyś się urodził. Dom, z którym wiązały się jego najszczęśliwsze wspomnienia, był teraz jak daleka, nieosiągalna ziemia obiecana. Trzy dni głodu pozbawiły go resztek sił. W nadziei znalezienia czegoś do zjedzenia zaglądał do różnych zagród, ale zewsząd go przeganiali. Poszukiwanie jedzenia na śmierdzącym śmietniku również nie przyniosło efektu.

${ }^{306}$ Ibidem, s. 222. 
Wierzchołek góry, u stóp której leżała jego rodzinna wieś, tonął w złocistych blaskach zachodzącego słońca. Poczuł się bezdomny i obcy w tej wyludnionej, smutnej wsi",307.

Bohater jest u kresu życia. Jest już stary. Dowiadujemy się, że wrócił do rodzinnej wioski po wielu latach smutnej egzystencji w obcych stronach, a wrócił, by tutaj umrzeć. Spogląda na rodzinną zagrodę, na sad, w którym niegdyś, w gorące letnie noce, baraszkował z koleżanką, a nad ranem odprowadzał ją do bramy i szczęśliwy kładł się do snu.

W miarę pogrążania się w lekturze czytelnik zaczyna domyślać się, że bohaterem opowiadania jest pies. „Kiedyś, w życiu które już dawno i bezpowrotnie odeszło, miał w tej zagrodzie własną budę, a gospodarz każdego dnia karmił go do syta. Lecz tym szczęśliwym dniom nie dane było trwać wiecznie"308. Kiedy zbliżał się front (mowa o konflikcie ormiańsko-azerbejdżańskim z lat 90.), wioskę zaczęli opuszczać mieszkańcy. Po staruszka, właściciela psa, przyjechał z miasta syn i kazał mu natychmiast z nim jechać - bez psa. „Z tego, jak staruszek gniewnie rozmawiał z synem i spoglądał w jego stronę, pies zrozumiał, że rzecz idzie o niego. Widać było, że stary człowiek chce go ze sobą zabrać, a syn się nie

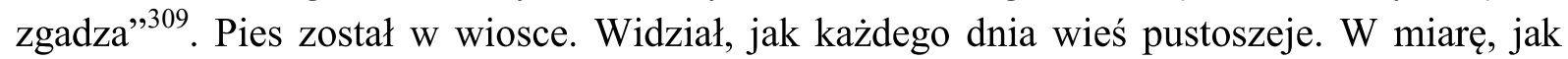
przybliżał się front, coraz więcej mieszkańców odjeżdżało na zawsze.

„Pewnej nocy Ormianie podeszli aż do wsi. I pies widział, jakich chwytali się podstępów, aby nastraszyć tych, którzy jeszcze pozostali w wiosce. Chciał o tym powiedzieć ziomkom, uspokoić ich, podtrzymać na duchu, ale cóż mógł zrobić... On, który rozumiał ludzką mowę, lecz nie potrafił mówić...

$\mathrm{Z}$ nastaniem jesieni wieś zajęli Ormianie.

Ostatnim, który opuścił wioskę, był pies"310.

Postrzelony w nogę, wlókł się dniami i nocami, aby dotrzeć do miasta. Wegetował tam wiele lat, co rano wychodząc z kryjówki i błąkając się po ulicach w nadziei na spotkanie swojego pana. „Nie wiedział, że myśl o ojczystej wsi, o porzuconym domu, w którym teraz gospodarują obcy, zabiła staruszka i że jego mogiła dawno już zarosła trawą"311. Pod koniec życia zapragnął wrócić do rodzinnej wioski, bo „nie chciał umierać na ulicy wielkiego miasta, jak ludzie"312. Dzień powrotu do domu okazał się ostatnim dniem w jego życiu. Mieszkający tu teraz gospodarz wyszedł ze strzelbą przed dom, gdy zobaczył obcego psa. Ten próbował ucieczki, ale kula dosięgła go w momencie, gdy przeskakiwał ponad ogrodzeniem. Ostatkiem sił dowlókł się do zarośli. Gasnącymi oczami spoglądał na przepiękny tego wieczoru zachód słońca, a wiejący od gór wiatr niósł w jego stronę zapach lasu - ,zapach znajomy i aż do bólu ojczysty" ${ }^{\prime 313}$.

\footnotetext{
${ }^{307}$ Eadem, Ojczyzna, [tłum.] G. Zając, Czerwona limuzyna..., op. cit., s. 131.

${ }^{308}$ Ibidem, s. 131-132.

${ }^{309}$ Ibidem, s. 132.

${ }^{310}$ Ibidem.

${ }^{311}$ Ibidem, s. 133.

${ }^{312}$ Ibidem.

${ }^{313}$ Ibidem, s. 134.
} 
Lista postaci w tym poruszającym opowiadaniu jest bardzo krótka. Głównym bohaterem jest pies i to o nim narrator opowiada od pierwszego do ostatniego zdania. Pojawiają się nieliczne inne postaci, ale wszystkie - albo poprzez wspomnienia psa (staruszek, jego syn, psia przyjaciółka z lat młodości), albo jako obraz widziany jego oczami (obcy gospodarz ze strzelbą). Narracja jest tak skonstruowana, że gdyby zamienić wszystkie czasowniki mówiące o psie (wszedł, spostrzegł, pojął, uciekł i in.) na postać pierwszoosobową, opowiadanie byłoby w takim samym stopniu zrozumiałe i równie (a może jeszcze bardziej) poruszające. Całe byłoby przeplataną retrospektywnymi wstawkami autoopowieścią o powrocie do ojczystej wioski.

Miejsca akcji utworu, oprócz tego zasadniczego - rodzinnej zagrody, do której powrócił stary pies - to przywoływana w jego wspomnieniach wiejska droga, gdzie po raz ostatni widział swojego pana i odprowadzał go wzrokiem aż po horyzont stepu oraz miasto, do którego udał się na długą poniewierkę.

Czas akcji utworu nie jest dokładnie określony, ale w przeciwieństwie do większości opowiadań Sultanlego wspomniane zostało konkretne wydarzenie z najnowszej historii, które pozwala na sprecyzowanie czasu: wojna ormiańsko-azerbejdżańska. Na czas akcji tego opowiadania, w którym główny bohater w jesieni swego życia wraca w rodzinne strony by tu umrzeć, nieprzypadkowo wybrano jesień, a dokładniej - piękny wieczór malowany krwistą czerwienią. Tragedia, która na koniec spotka psa, zapowiadana jest już na początku akcji właśnie tą barwą: „Chmury pełne wieczornego koloru jesieni zdawały się być gotowe do wylania potoków gorącej krwi"314.

\section{Podsumowanie}

Bohater, czas i miejsce/przestrzeń to główne elementy fabuły gatunku, który nazywamy opowiadaniem. W utworach Vaqifa Sultanlego między tymi trzema elementami zachodzi szczególnie silna i specyficzna więź. Mówiąc 'specyficzna' mam na myśli przede wszystkim fakt, że jego bohaterowie są bardzo mocno osadzeni w konkretnych miejscach, które mają fundamentalne znaczenie w życiu tych osób, a zwłaszcza mają decydujące znaczenie dla przebiegu akcji; a z kolei te miejsca są silnie związane z czasem, który przesądza o takim a nie innym biegu wydarzeń. Uważna lektura opowiadań Vaqifa Sultanlego pozwala zauważyć, jak wielką rolę przywiązuje on do wzajemnych oddziaływań między tymi trzema zasadniczymi częściami składowymi fabuły. Odnosi się wrażenie, że autor starannie dobiera człowieka, czas i miejsce, tak aby żaden z tych elementów nie był przypadkowy. Nawet wzmianki o pogodzie, o barwach towarzyszących porze roku czy porze dnia, o odgłosach dobiegających z otaczającej miejsce akcji przyrody - zdają się być bardzo starannie przemyślane, tak aby współgrały $z$ toczącym się dramatem i uzupełniały go (bo trudno nie zauważyć, że w utworach Sultanlego rozgrywają się mniejsze lub większe dramaty).

Bohaterowie utworów Vaqifa Sultanlego znacznie częściej są postaciami pozytywnymi, a typów całkiem negatywnych nie spotykamy prawie wcale, chyba że we wspomnieniach innych bohaterów. Jeśli nawet naszej lekturze towarzyszy uczucie sprzeciwu wobec postaw niektórych bohaterów (jak na przykład postawa kobiety wyrzucającej z domu w mroźną zimę

${ }^{314}$ Ibidem, s. 131. 
kotkę z nowo narodzonymi kociętami lub postawa człowieka, który zabierając do siebie starego ojca odmawia zabrania również jego psa), to zachowania tych ludzi tłumaczymy raczej brakiem wiedzy, przesądem, uprzedzeniem, ubóstwem, a nie złym charakterem człowieka.

Bardzo często bohaterom towarzyszą smutne wydarzenia; śmierć, żałoba, wojna, ucieczka, utrata, samotność. Mimo to wyczuwa się ledwie uchwytną pogodę ducha, nawet w obliczu śmierci. Jest to pogoda ducha człowieka pogodzonego z losem. Pogodzonego i pogodnego. Człowieka, który nie zamierza szarpać się z losem. Pewnie dlatego opowiadania Sultanlego nigdy nie mają szczęśliwego, radosnego zakończenia. Warto w tym miejscu dodać, że postaci bardzo często mają problemy natury psychicznej, cierpią z powodu samotności, odrzucenia, wewnętrznego niepokoju.

Akcja utworów Vaqifa Sultanlego toczy się bardzo powoli, jest spokojna, niekiedy nawet statyczna, i tacy też są bohaterowie. Prowadzone przez nich dialogi są krótkie, złożone najczęściej $\mathrm{z}$ bardzo prostych lub urwanych zdań. Najczęściej zresztą dialogów w opowiadaniach Sultanlego nie ma prawie wcale. Bohaterowie sprawiają wrażenie zmęczonych, a przez to wyciszonych. Jest to zmęczenie fizyczne, które towarzyszy człowiekowi po ciężkiej pracy, ale równocześnie jest to zmęczenie życiem.

Akcja opowiadań obraca się przeważnie wokół jednej osoby. Postaci drugoplanowe (często są nimi zwierzęta) odgrywają jednak bardzo ważną rolę, wzbogacając fabułę lub determinując losy głównego bohatera. U Sultanlego zwraca uwagę częste wykorzystywanie postaci ze świata zwierząt. Są to towarzysze życia człowieka: koń, pies, kot; ale także inne zwierzęta żyjące w ludzkim sąsiedztwie, jak ptaki, węże. Na pytanie, dlaczego tak często wykorzystuje w opowiadaniach obraz zwierząt, Sultanlı odpowiedział: „Wybieram postaci zwierzęce w charakterze pewnych symboli, aby pełniej odzwierciedlić ludzkie problemy. Zwierzęta są doskonałym materiałem do wyrażania w literaturze znaczeń metaforycznych"315. Zupełnie nadzwyczajną rolę pełni zwierzę w opowiadaniu Ojczyzna. Główny bohater, pies, zestawiany jest z ludźmi, a ta konfrontacja wypada niezwykle korzystnie dla zwierzęcia. Jest on tym mieszkańcem wsi, który opuścił ją jako ostatni. Czytelnik odbiera jego postawę jako odważną. To ludzie bali się ostrzału, przegranej wojny i trafienia w ręce wroga. On - nie. To on marzył, aby jego rodacy odbili wieś i nie rozumiał, dlaczego tego nie robią. Ludzie tylko mówili, że trzeba by ją odbić, lecz nikt się do tego nie rwał. To on chciał umrzeć godnie, na rodzinnej ziemi, a nie na ulicy w obcym miejscu, jak to się przytrafia ludziom. Wreszcie to on pozostawia w czytelniku obraz istoty oddanej i wiernej do końca.

W utworach Vaqifa Sultanlego powszechnie pojawia się śmierć, jeśli nie w akcji rzeczywistej utworu, to we wspomnieniach bohatera. Jest to albo śmierć, która zabiera głównego bohatera bądź kogoś z jego bliskich, albo śmierć, przed którą bohater ucieka. W związku z tym, dość powszechnym miejscem pojawiającym się w tych utworach jest cmentarz. Innym ważnym determinantem ludzkich (i zwierzęcych) losów jest wojna, która drastycznie zmienia życie bohaterów Vaqifa Sultanlego. Wojna jest w jego utworach wydarzeniem z przeszłości, dowiadujemy się o niej dzięki retrospekcji, która w twórczości tego pisarza jest bardzo ważną dominantą konstrukcyjną. Umiejętnie wplatana w akcję, przerywa na chwilę właściwy bieg wydarzeń, ale bynajmniej nie komplikuje struktury

\footnotetext{
${ }^{315}$ Cytat z korespondencji autorki z pisarzem (jesień 2019).
} 
utworu, ani nie zaburza porządku; wręcz przeciwnie, uzupełnia, wzbogaca, umożliwia szersze spojrzenie na bohatera i toczące się wypadki. Niejednokrotnie retrospekcja ma kluczowe znaczenie dla całej fabuły. Widać to choćby w opowiadaniu Ojczyzna, w którym bez wspomnienia o ormiańskiej agresji i o wywołanej nią ucieczce mieszkańców - trudno byłoby pojąć ogrom rozgrywającej się psiej tragedii.

Kiedy analizujemy czas przedstawiony w opowiadaniach Vaqifa Sultanlego, dochodzimy do stwierdzenia, że przeważnie oznacza on czas PO CZYMŚ. Po czymś, co się skończyło, odeszło bezpowrotnie lub zostało odebrane, pozostawiając smutek, żałobę czy poczucie utraty czegoś drogiego.

W opowiadaniu Zapach piotunu jest to czas po przedwczesnej, niespodziewanej śmierci matki. W opowiadaniu Kilim Babci Ínce - czas po bliżej nieokreślonej wojnie, która zabrała staruszce wnuków. W opowiadaniu Ojczyzna mamy czas po wojnie ormiańskoazerbejdżańskiej, która zmusiła całe wioski do porzucenia dobytku i ucieczki przed wrogiem. I wreszcie opowiadanie Buraska, gdzie akcja zaczyna się po nocnym porodzie, w wyniku którego na świat przychodzi chłopiec. Tym razem akcja nie zaczyna się po wydarzeniu smutnym, bo narodziny chłopca wnoszą do tego domu radość. Jednak to radosne dla domowników wydarzenie nie będzie szczęśliwe dla wszystkich - tytułowej kotce i jej nowo narodzonym dzieciom przyniesie śmierć. Ale także i w tym opowiadaniu dostrzegamy detal, poprzez który autor daje nam do zrozumienia, że szczęśliwe narodziny chłopca w tej rodzinie nastąpiły po czymś (w mniemaniu tych ludzi) mniej szczęśliwym: syn przyszedł na świat po tym, jak kobieta urodziła swemu mężowi cztery córki...

Opowiadania Vaqifa Sultanlego to panorama XX-wiecznego Azerbejdżanu $\mathrm{z}$ przełomu ostatnich dziesięcioleci władzy radzieckiej i niepodległej Republiki. Pokazują człowieka w miejscu, w którym żyje - najczęściej jest to wnętrze domu i najbliższe otoczenie. Akcja rzadko toczy się w mieście, a ulubionym miejscem wybieranym przez pisarza jest mała miejscowość na prowincji. Sultanlı kreuje bohatera przez pryzmat jego czynów, przeżyć i marzeń. Pozwala $\mathrm{w}$ ten sposób czytelnikowi na bliższe przyjrzenie się uwarunkowanej sytuacją polityczną kondycji ekonomicznej i psychicznej prostych mieszkańców kraju, na poznanie ich dramatów, trosk i marzeń. Utwory te stanowić więc mogą uzupełniające źródło wiedzy dla badaczy współczesnego Azerbejdżanu, bo - chociaż literatura piękna nie jest dokumentem dla politologa, historyka czy socjologa - to z całą pewnością jest interpretacją faktów historycznych oraz zjawisk politycznych i społecznych. Przeinaczając nieco stwierdzenie Nietzschego $^{316}$ można powiedzieć, że na równi $\mathrm{z}$ faktami istnieją też interpretacje tych faktów.

Warto też na koniec dodać, że dla osób zainteresowanych współczesnym Azerbejdżanem i literaturą azerbejdżańską utwory Sultanlego mogą być wartościową lekturą, dostarczającą wielu pozytywnych wrażeń estetycznych i duchowych. Jest to starannie dopracowana i dobrze przemyślana proza, pisana pięknym, bezpretensjonalnym językiem. $\mathrm{Z}$ pewnością zasługuje na przekład i przybliżenie polskiemu czytelnikowi.

\footnotetext{
316 „Przeciwko pozytywizmowi, który zatrzymuje się przy zjawisku «istnieją tylko fakty», powiedziałbym: nie, właśnie fakty nie istnieją, tylko interpretacje”. F. Nietzsche, Pisma pozostałe, t. 2, Kraków 1994 [tłum.] B. Baran, [cyt. za:] A. Burzyńska, M. P. Markowski, Teorie literatury XX wieku, Kraków 2007, s. 497.
} 


\section{Streszczenie:}

$\mathrm{W}$ artykule autorka podejmuje próbę przeanalizowania trzech komponentów, które pełnią bardzo ważną rolę w fabule opowiadań azerbejdżańskiego pisarza Vaqifa Sultanlego (ur. 1958). Są to: człowiek, czas i miejsce. Część pierwsza to krótkie, teoretyczne rozważanie na temat roli czasu i miejsca w dziele literackim. Następnie przedstawia się pisarza wraz z jego osiągnięciami naukowymi i literackimi. Zasadnicza część artykułu skupia się na analizie czterech wybranych opowiadań Vaqifa Sultanlego pochodzących z różnych okresów jego twórczości. Jak wykaże przeprowadzona analiza, w utworach omawianego pisarza zachodzi bardzo silna więź między kategoriami 'bohater', 'czas' i 'miejsce'. Pisarz często korzysta z retrospekcji, co pozwala na wzbogacenie fabuły o istotne treści. W ten sposób czytelnik poznaje smutną przeszłość bohaterów, determinowaną przez tragiczną historię narodu: przez wojny, śmierć, wygnanie.

\section{Słowa kluczowe:}

radziecki Azerbejdżan, współczesna proza azerbejdżańska, Vaqif Sultanlı, bohater literacki, kategorie czasu i miejsca

\section{Keywords:}

Soviet Azerbaijan, contemporary Azerbaijani prose, Vagif Sultanl1, a character in literature, the categories of time and place.

\section{Bibliografia:}

1. M. Bachtin, Formy czasu i czasoprzestrzeni w powieści, [w:] eadem, Problemy literatury i estetyki, [tłum.] W. Grajewski, Warszawa 1981

A. Burzyńska, M. P. Markowski, Teorie literatury XX wieku, Kraków 2007

2. Güney Azərbaycan nəsri. Başlanğıcdan bu günə qədər, [haz.] V. Sultanlı ile İ. İsmayıl, Bak1 2017

3. E. Cassirer, Esej o człowieku. Wstęp do filozofii kultury, [tłum.] A. Staniewska, Warszawa 1977

4. T. Gęsina, Co było przed geopoetyką? Kategoria przestrzeni w literaturoznawstwie polskim - rekonesans, „Postscriptum Polonistyczne” 2016, nr 1 (17), s. 167-178

5. S. Koşmaz, Vaqif Sultanlı'nın Hikâyelerinin İncelenmesi (yüksek lisans tezi), Bartın $2016<$ http://acikerisim.bartin.edu.tr:8080/xmlui/handle/11772/220>

6. H. Markiewicz, Czas i przestrzeń w utworach narracyjnych, Kraków 1983, [nadb.] „Ruch Literacki”, XXIV, z. 1 (136), s. 1-12

7. Martuszewska, Czas i przestrzeń w polskiej powieści współczesnej dojrzałego realizmu, „Pamiętnik Literacki” 1975, 66/1, s. 3-23 
8. Modern Azerbaijanian Prose. Anthology, prep. by V. Sultanly and I. Ismaely, Bloomington, 2012; 2nd edition with additions, eidem, Bloomington, 2019

9. Modern Azerbaijani Women's Prose. Anthology, eidem, Bloomington, 2014

10. V. Sultanlı, İncə qarının hanas1, [w:] Qul bazarı, Bakı 1999, s. 90-91

11. V. Sultanl1, Vətən, [w:] Ölüm yuxusu, Bakı 2002, s. 129-132

12. V. Sultanlı, Ojczyzna, [tłum.] G. Zając, [w:] Czerwona limuzyna. Antologia współczesnej prozy azerbejdżańskiej, Warszawa 2007, s. 131-134

13. V. Sultanl, Xall1, [w:] Qul bazarı, Bakı 1999, s. 76-80

14. V. Sultanlı, Buraska, [tłum.] G. Zając, „Przegląd Orientalistyczny” nr 3-4 (2007), s. 221-223

15. V. Sultanl1, Yovşan ətri, [w:] Qul bazarı, Bakı 1999, s. 14-19 